\title{
The Meaning of Prayer: A Christian Physician's Experience
}

\author{
THOMAS E. ELKINS \\ DOUGLAS BROWN
}

\begin{abstract}
Christians in health care need a habit of prayer that allows them to express to God the full range of their reactions to daily experience. All of life can become the occasion for prayer when understood as communion or conversation. After brief commentary on this view of prayer, actual prayers are shared, demonstrating one Christian physician's attempts to "pray without ceasing."
\end{abstract}

At our mission hospital in the tropical rain forest of Nigeria, an almost trancelike calm precedes most labor and delivery scenes. However, on this day, a young patient screamed hysterically as we prepared to anesthetize her for a C-Section. The aides began shouting, "Make you lie still. We de pray for you now. We de try-oh. Make you be still now." Silence followed. Their prayer began with the Urhobo word for "our father" - "ezyerrogeherro." When repeated, this deeply guttural word spread over the room with a rolling sound and invariably brought with it peace.

Patients came to that hospital with overwhelming problems-tumors, bowel obstructions several days old, starvation, and malaria. Nigeria is more progressive economically and socially than many African nations, but that hospital had many more patients than it had capacity to handle. And yet they continued to come - the eclamptic patient who had already been having seizures at home, the hemorrhaging patient almost dead in shock, and mothers saddened by deliveries that had gone wrong in the village, leaving dead babies inside them that would not come out of their wombs.

In those peaceful moments of prayer before surgery, I found the courage to continue when the cases were discouraging and the results were less than ideal. Those simple rural people expressed a sense of gratitude after each case,

Thomas E. Elkins, M.D., is Chief of Gynecology at the University of Michigan's Medical School. Douglas Brown, Ph.D., is Associate Professor of Theology at Harding University Graduate School of Religion in Memphis, Tennessee.

This paper is part of a forthcoming book to be published by Broadman.

All personal references in the article are to Dr. Elkins. 
to God as much as or more than to the "oyeebo" doctors whose hands had been the instruments in the healing effort. "We thank God" were the unashamed post-op words of almost every family.

That Nigerian atmosphere of prayer has proved difficult to reproduce in the United States. Here patients' reactions to intervention, divine or human, into their situations are far less predictable. Is dependence an "all or nothing" matter? Like many others, I have experienced the extremes of the spectrum.

Signs lined the crowded corridor walls of a major city's charity hospital, reminding those present: "Quiet please! This IS a hospital." No other area of the hospital approached the noise and confusion of labor and delivery. The labor "rooms" were actually long rows of hospital beds separated only by curtains. "Regional anesthesia" (when laboring women had their pain removed by epidural anesthesia) was not yet in use and "twilight sleep" (when women were put to sleep through labor and delivery) had been discarded. In other words, with only minimal pain medication and anesthesia being used, those labor "rooms" were plain loud. With each contraction, many women on the ward responded ethnically. Mexican Americans cried out, "Aiyee! Aiyee! Aiyee!" Blacks shouted, "Lordie, Lordie, Lordie!" Not a few punctuated their shouts with profane expletives.

On one particular night, a teenage girl stood out from the rest. She was too young, probably not more than fifteen. Labor surpassed her comprehension. Like lightning before thunder, the wide-eyed glare of horror with which she met each contraction portended inevitable shrieks. She had received no prenatal care before labor. She expected "the Lord" to care for her. Then labor began. With each painful contraction, she rose to her knees and shouted at the ceiling, “Jesus! Jesus! Jesus! Help me, Jesus! Help me!" More than once, she became so vigorous in her exhortation of Jesus that she stood in the rolling bed to leave no doubt about her point. Medical students in surgical greens and nurses in once-white uniforms raced to her bed to pull her back down, warning her of the danger of this behavior.

This cycle of patient reaction and professional response went on for several hours. Finally, as labor neared an end, she rose to her knees one last time and shouted louder than ever before: “Jesus! Jesus! Oh, Jesus! You ain't helpin' me a bit!"

This young mother delivered shortly after that outburst, to the relief of all attending her. Still, her cries left an indelible image in my mind. She represents extreme reliance on others - family, health care professionals, or, in her case, God. But the opposite extreme is equally distressing, and occasionally just as humorous. Some are determined to trust no one.

A pregnant health care professional sought the care of midwives in order to have "a more natural birth." Even when found to be carrying twins, she remained firm in her decision to avoid obstetricians. She came to deliver while I was on call in labor and delivery. Repeatedly tossing any cover aside, she lay nude on a hospital stretcher, writhing with each contraction and angrily re- 
fusing all medical attention. Her husband flitted about, taking pictures of her performance. The nurse midwife finally came to us for help. She had concluded that this couple was so fixed on "the shared experience of natural childbirth" that all concern for the twins had been forgotten.

Upon entering the room, I felt the glares reserved for any intruding obstetrician. I did not think of myself as their adversary. Natural childbirth, especially when accompanied by competent midwifery and excellent prenatal care, can be a rewarding experience. My concerns in this case were parental motivation and fetal complications. Nevertheless, both wife and husband rigidly refused my request to monitor the babies to assess their positions. They even resisted the precautionary measure of making routine provisions for a complicated birth. Frustrated, I stepped out of the room.

My thoughts drifted to the pleading eyes of laboring mothers I had treated in Africa. For them, natural childbirth was an often tragic necessity rather than a desired luxury. They labored in the fields until hours (or even minutes) before delivery and, restrained by their culture's traditions, many times never uttered a sound. About 185 out of every 1,000 African newborns died within two weeks. When weak mothers finally were brought to a hospital with a difficult or impossible delivery, almost ten percent of the mothers died of prolonged hemorrhage, infection, or toxemia despite aggressive therapy.

I recalled a diary letter I had written in Ghand, West Africa:

Tropical, third-world obstetrics - what disasters those few words imply. The past two days have been filled with complications found where medical care is either unavailable or is not sought in a timely fashion.

An eighteen-year-old girl lay seizing in women's ward. She had been ill for three days, receiving "black medicine" in the village for two days. The signs of eclampsia, or "toxemia of pregnancy," were obvious - puffy hands and face, low urine output, high blood pressure, and large, tender liver. She also had a severe case of malaria. Probably some of her diminished brain function was due to that. Only about twenty-six weeks into the forty-week pregnancy, she would not see another week without aggressive care, including induced or operative delivery.

At the same time, we were already operating on a "VVF" - the common phrase here for vessico-vaginal fistula. A hole forms in the bladder or urethra because the patient is in labor so long that the tissue under such pressure in the pelvis finally breaks down, dies, and dissolves, leaving a constant urine leakage from that day forward. Many are so large that they cannot be repaired successfully with any kind of primary closure. All would have been prevented by a timely C-section.

But we should consider our last ten days fortunate. We've had no ruptured uterus cases presenting in shock with hemorrhage, and no babies mangled by village caretakers. In America, the expectation of perfect outcome from pregnancy often leads to the demand for nonintervention by a physician in pursuit of the natural way ... ignoring history's (and the current day third world's) legacy of obstetrical disasters, so visible at Nalerigu. 
In that hospital corridor, as I mulled over what to do next, the faces of those women flashed before me. The lives of the children and the pleading faces of those victims of the unattended childbirths in Africa restored my diminished resolve. I re-entered the room.

We had a sobering discussion about child abuse and neglect, and about legal liability. Finally, the camera stopped clicking. The parents decided to give the coming twins their attention and the benefit of the available medical personnel's abilities. We later delivered two normal twins.

From such contrasting experiences with ways patients handle dependence on medical help, my thoughts about prayer and care for the suffering have evolved. I am convinced all of life becomes a prayer, when prayer is understood to be communion or conversation with God. In this way, Christians have the opportunity to express to God the full range of their reactions to daily experiences.

Instead of discussing this view of prayer, I have chosen to share some prayers from my attempts, beginning in medical school, to "pray without ceasing." The texts from Scripture point to the common ground between these present experiences and the experiences recorded in Scripture, thereby establishing a resonance between my prayers and the prayers of old.

\section{First day}

Have you not known? Have you not heard? The Lord is the everlasting God, the Creator of the ends of the earth. He does not faint or grow weary, his understanding is unsearchable. He gives power to the faint, and to him who has no might he increases strength. Even youths shall faint and be weary, and young men shall fall exhausted; but they who wait for the Lord shall renew their strength, they shall mount up with wings like eagles, they shall run and not be weary, they shall walk and not faint. (Isaiah 40:28-31)

Therefore, I tell you, do not be anxious about your life. ... Therefore, do not be anxious about tomorrow, for tomorrow will be anxious for itself. Let the day's own trouble be sufficient for the day. (Matthew 6:25, 34)

Lord, as suavely as possible,

I glided into the crowded lobby

Radiating confidence and charm.

Immediately, I found myself talking-

One guy was a member of the Yale swimming team,

And I thought meekly of my record as a Baylor bear-pit cleaner;

The other was a chemistry major at Rice who had already placed out of biochem,

And I almost told him how my religion major placed me out of nothing. 
Having had the fine edge of confidence rounded off a little, I stumbled into the first class

And was promptly shattered.

A problem sheet,

Containing all the freshman chemistry

That I never bothered to learn

Was distributed to be done as review!

By noon,

Being sufficiently panic-stricken,

I grimly stalked into the bookstore,

And spent the lunch hour buying about two hundred

dollars worth of texts.

Armed thus, I strode into gross anatomy-

Tight-lipped, with renewed vigor and determination.

The cadaver had only been out a few minutes.

Surrounded by the smell and

appearance of dead bodies,

My surgeon-like strokes

Almost cut off the top of my left index finger.

After a short conference,

The professor-doctors decided stitches were not

necessary,

And I trudged toward home.

Reeking of formaldehyde and protecting a throbbing finger,

I flopped down at the beautiful study desk purchased by my parents,

Who perhaps had been a little overly proud and expectant since my acceptance,

And began to read the packet that had been handed to us at 8:00 A.M.

The first leaflet read: "Welcome to Baylor college of Medicine."

I have to admit, Lord, I am anxious about tomorrow.

\section{The Taub}

Then the King will say to those at his right hand, "Come, O blessed of my Father, inherit the kingdom prepared for you from the foundation of the world; for I was hungry and you gave me food, I was thirsty and you gave me drink, I was a stranger and you welcomed me, I was naked and you clothed me, I was sick and you visited me, I was in prison and you came to me." Then the righteous will answer him, "Lord, when did we see thee hungry and feed thee, or thirsty and give thee drink? And when did we see thee a stranger and welcome thee, or naked and clothe thee? And when did we see thee sick or in prison and visit thee?" And the 
King will answer them, "Truly, I say to you, as you did it to one of the least of these my brethren, you did it to me." (Matthew 25:34-40)

Lord, the patients at Ben Taub General Hospital, the Harris County Charity institution, arewhat is a kind word-indigent? poor?

These are truly sick people.

The mortality rate for in-patients at Ben Taub is tremendously high -

Forgetful doctors in private practices state with contempt,

"It is this way because these patients are subjected to the medical ignorance of students and house staff."

Those of us who work at "The Tub" know differently.

The only way one can be admitted for a total diagnostic workup is to be suspected of having one of the true "facinomas" of medicine, for only the password "exotic disease" allows these people to the hospital shakedown that their wealthier brothers receive routinely.

It is at this place - with its dirty walls, its dark stairwells, its open wards crowded with oozing sores and fevers -

that we have begun to learn about medicine.

We learn that medicine is synonymous here with rushing furiously to wait in another line or climbing three flights of stairs to get $x$-rays that cannot be found.

We learn that patients do suffer because of our ignorance and that our frustrations mount as we become almost desperate, at times, to do more than we are able.

And through it all, the patients continue to trundle through: the pedi's with aching ears, the ladies of the night with V.D., the young or old with tumors, the mentally deranged, the drunks, and those who come to die.

And with them all, you too, Lord, continue to trundle through.

\section{Alpha and omega}

For everything there is a season, and a time for every matter under heaven: a time to be born, and a time to die. (Ecclesiastes 3:1-2a) Bear one another's burdens, and so fulfill the law of Christ. (Galatians 6:2) 
Lord, an elderly black man

With sunken eyes protected by large cheek bones,

And arms that were too thin,

And a body that appeared to be too long,

Looked over the sheet at us

As we walked into his room.

In a slow Louisiana drawl with Cajun accent,

He told us about his pain

That was carried away with bi-weekly transfusions,

And then returned to haunt him again more quickly

than the time before.

We learned about his boyhood in Louisiana

And his job as a Texas laborer.

We talked about his family,

And learned new medical terms like "dropsy" and "low

blood."

Sprinkled in his stories

Were litle hints of swollen glands

And recognitions of aching joints.

The elderly black man

Was the first patient I ever interviewed.

He was also my introduction to leukemia.

I never saw him again,

But he had strengthened me;

For his aging eyes had seen that we were too young and too nervous

To be real doctors.

Yet he trusted our white coats enough to confide in us.

Somewhere in that tired face was

A glimmer of contentment as we left,

Because it was obvious that his time was soon over

And that our time was just beginning.

I think he wanted to participate in this beginning of our

professional life,

To do more than just watch his life end.

I was eager to accept all the responsibility

That goes with accepting a man's trust,

And I pray I always will be.

The county emergency room

By this we know love, that he laid down his life for us; and we ought to lay down our lives for the brethren. But if any one has the world's goods and sees his 
brother in need, yet closes his heart against him, how does God's love abide in him? Little children, let us not love in word or speech but in deed and in truth. By this we shall know that we are of the truth, and reassure our hearts before him. ... (1 John 3:16-19)

O my Lord,

Are these your children

Who stand cramped, or lie crumpled, in the halls of "the Tub"

Because the entire supply of chairs and stretchers is exhausted?

Everywhere I look I see unpleasant faces

Spelling out their anger at having to wait for us,

Revealing the pain that cripples the mind and body,

And coughing up their drunkenness onto our clothes and into our faces.

This mass of ugliness, with the stench of infection and the dreariness of oozing wounds,

Becomes monotonous in its volume.

O my Lord, my God,

Did Jesus die for these?

Are these who sweat and smell and bleed

Part of the beauty of life?

And I already know Your answer.

For this is the struggle to exist at gut level.

Through the despair of this night,

Most of these faces will gain strength enough

To catch sight of the beauty of tomorrow.

It is through this essential witnessing of pain and death

That we are reminded we have also experienced joy in Your world.

So, in answering the call of physical anguish,

We are freed to worship in creativity.

It is so simple and pure that $I$ forget it

And find myself cold and aloof, mechanically dealing with pain.

Help me, O Lord,

To remember that the ugliness of this night

Is more within those of us who reject the power of

Your love to show kindness.

If I can suture every wound and set every I.V.

And still hide Your boundless love from these people,

Then I have served only my ego.

There are many egos and many heroes here, 
But few who seem concerned for their fellow human beings.

O Jesus, who died for all of these,

Show me the way to expose that glimmer of Your love

within all people,

And teach me to love fully, even here.

\section{Death}

When the perishable puts on the imperishable, and the mortal puts on immortality, then shall come to pass the saying that is written: "Death is swallowed up in victory." "O death, where is thy victory? O death, where is thy sting?" The sting of death is $\sin$, and the power of $\sin$ is the law. But thanks be to God, who gives us the victory through our Lord Jesus Christ. Therefore, my beloved brethren, be steadfast, immovable, always abounding in the work of the Lord, knowing that in the Lord your labor is not in vain. (1 Corinthians 15:54-58).

Death,

I struggled with you for the first time this year.

I have seen the panic on the faces of those who see you near.

I have seen you steal away the joy of life

And trample hope into meaningless existence.

I watched all this in ignorance and silence;

And, afterward, questions burned in my mind -

Of the twenty-seven-year-old black man

who came laughing, joking, strolling into the ward, and was paralyzed one day later.

Would he walk today if we had found his tumor even

two hours earlier?

Of the courageous thirty-eight-year-old man

raising his stiffened, withered hand to greet us,

and remaining alert and hopeful until his lungs

finally filled with pneumonia.

Had all our technology only aided Death by prolonging human suffering?

Of an old, ragged, cursing loner

who came in with only a name and a stone-like throat.

He lay reeking of alcohol, shriveled, cold, and

hungry, wavering in and out of reality;

until the early morning when, bewildered,

we found him quiet and still.

My God, could we have given this man the health to

know Your full life?

Had we failed not only him, but You also? 
Like a lame coward

I met you, Death,

On a training field called the V.A. Hospital

And you stomped me and all my boyhood dreams of grandeur into a thousand pieces.

I found myself wishing I was still in a classroom somewhere,

Or playing one-on-one basketball while skipping psychiatry lectures.

I wanted to be a little boy again,

To worry about Friday's game after school,

Or even tomorrow's math test.

I was suddenly faced with ultimate questions of life and death,

And realized the woefully inadequate level of my medical and moral insights.

As a child of ignorance, I beg you, O Father,

To define life for me in every instance,

To help me contribute to life as You make it,

And never to be an aid to Death.

Detail Your will for me, telling when to treat and when to console.

I feel that You have thrown me into a dark void, proving to me that my tiny bit of knowledge is vanity without Your gift of purpose.

But, in so doing,

You are bringing me out of childhood

And I often feel older than my years.

Death, you, too, have molded and tempered me

Into a more worthy opponent.

I promise you I will be less ignorant in our next meeting.

I intend that you will not know of easy conquest again.

For, if I will let the power of Christ work through me,

You, Death, perhaps will bring no anguish and cause no fear.

\section{First delivery}

And they were bringing children to him, that he might touch them; and the disciples rebuked them. But when Jesus saw it he was indignant, and said to them, "Let the children come to me, do not hinder them; for to such belongs the kingdom of God. Truly, I say to you, whoever does not receive the kingdom of God like a child shall not enter it." And he took them in his arms and blessed them, laying his hands upon them. (Mark 10:13-16) 
The whole scene is enough to make you faint the first time.

Some unknown lady is rhythmically chanting, "Aiyee, aiyee, aiyee";

And in the delivery position, a woman's figure becomes an ominous, glaring foe.

But this was "do one" day for me in Baylor's system of see one, do one, teach one.

I scrubbed for at least fifteen minutes, hoping someone else would have to deliver the baby,

And then found that I couldn't get into my own pair of gloves.

After all preparations were done, I stood confidently, basking in the glow of my vast experience,

As I tried to prepare myself for the birth of the baby.

With knees shaking and glasses completely fogged over,

I dimly saw the top of a head coming into view.

I reached with both hands to grasp the little bugger,

Could find no non-slippery surfaces to grasp,

And so, caught the expelled child in the basket of my arms.

On seeing this amazing maneuver, the chief resident

screamed, "No, no!"

He raced over and grasped the squirming child in one hand

And shouted, "You've got to grab the kid, like this, see!"

I saw, and actually at that time,

with the baby crying, the mother gasping, and my knees

resembling a rippling brook,

I was glad for anybody other than me to hold the baby.

\section{Deranged but human}

They came to the other side of the sea, to the country of the Gerasenes. And when he had come out of the boat, there met him out of the tombs a man with an unclean spirit, who lived among the tombs; and no one could bind him any more, even with a chain; for he had often been bound with fetters and chains, but the chains he wrenched apart, and the fetters he broke in pieces; and no one had the strength to subdue him. Night and day among the tombs and on the mountains he was always crying out, and bruising himself with stones. And when he saw Jesus from afar, he ran and worshipped him; and crying out with a loud voice, he said, "What have you to do with me, Jesus, Son of the Most High God? I adjure you by God, do not torment me." For he had said to him, "Come out of the man, you unclean spirit?" And Jesus asked him, "What is your name?" He replied, "My name is legion; for we are many." And he begged him eagerly not to send them out of the country. Now a great heard of swine was feeding there on the hillside; and they begged him, "Send us to the swine, let us enter them." So he gave them leave. And the unclean spirits came out, and entered the swine; and the herd, numbering 
about two thousand, rushed down the steep bank into the sea, and were drowned in the sea. (Mark 5:1-13)

On his five-foot frame, two hundred pounds of soft flesh shimmered.

Tremendously thick glasses covered his eyes,

And a face, noted mostly for protruding front teeth,

Peered out from under very long, matted hair.

Clad only in blue swim trunks, he had appeared in the emergency room,

Shouting, "Thou hast not known me, but thou mayest yet know

I am the Christ."

As we began to laugh at this spectacle,

He raised his transistor radio and argued that it was

his direct communication with God.

It all seemed funny, then.

This comic-strip character was too unreal to cause much worry on our part.

Less than forty-eight hours later, I saw him again.

He sat in a padded cubicle, rhythmically banging his head on the wall;

He rolled his eyes,

Clawed at his face,

And jammed his fingers far into his mouth.

On seeing me through a small window,

He leaped up and charged at the door.

His face twisted with pain.

His eyes glaring at mine, he began to scream profanities into my face,

And would have destroyed me, I'm sure, if a door had not separated us.

Schizophrenia -

I had been introduced to the tragedy of "split personality," and it had scared me.

I felt weak, nauseated, and afraid.

The power of the subconscious mind was far too real for my world.

Born to love

Love is patient and kind; love is not jealous or boastful; it is not arrogant or rude. Love does not insist on its own way; it is not irritable or resentful; it does not re- 
joice at wrong, but rejoices in the right. Love bears all things, believes all things, hopes all things, endures all things. Love never ends. . . (1 Corinthians 13:4-8a)

Love has seen this nine-month-old child

And has brought him here to us.

Though blind and deaf, he will know of life.

He will feel the warmth of my hands,

The brush of my fingertips on his head,

And the soft wisp of my breath against his cheeks.

I want so much to see him smile, to see him laugh.

His pain is mine to ease; his life ours to live.

Love has truly seen this child

And has brought him here to us,

That we may express our love for this helpless one,

And, also, that we may open our eyes to each other-

Our studious, curious eyes that are so often blind;

And that we may open our ears to each other-

Our ringing, harassed ears that are so often deaf;

That we may love all people,

As we love this helpless child.

\section{Unity}

But now in Christ Jesus you who once were far off have been brought near in the blood of Christ. For he is our peace, who has made us both one, and has broken down the dividing wall of hostility, by abolishing in his flesh the law of commandments and ordinances, that he might create in himself one new man in place of the two, so making peace, and might reconcile us both to God in one body through the cross, thereby bringing the hostility to an end. And he came and preached peace to you who were far off and peace to those who were near; for through him we both have access in one Spirit to the Father. (Ephesians 2:13-18)

After delivering nine babies of three different races,

I hear again a soft voice that says,

"We are of one Man."

And, yet, we build fences around our homes

We whisper secrets behind another's back

We code by races and creeds

We fight wars every few years

We protect a rigid social structure and always dress appropriately.

But I still hear that soft, quiet voice that says,

"We are of one Man-

We are born 
We suffer

We love

We laugh

We all die."

That voice whispers to those who will listen

In crowded streets and offices

In open fields and hills

In luxurious hotels and clubs

In charity emergency rooms and dimly lit medicine wards.

And here,

The voice that whispers becomes a shout-

"WE ARE OF ONE MAN,"

The Son of Man

Who has broken down every dividing wall

And knows all human beings as one beloved creation. 